\section{Creatine Phosphokinase Isoenzymes}

Creatine phosphokinase (adenosine triphosphate: creatine phosphotransferase) has been shown by electrophoretic separation on agar gel and starch gel to exist in multiple molecular forms (isocnzymes) ${ }^{1-3}$. This communication describes a staining technique for creatine phosphokinase (CPK) and its application to the demonstration of CPK isoenzymes separated on cellulose acetate membranes.

Tissue homogenates and sera $(5 \mu \mathrm{l}$.) are separated on cellulose acetate membranes ${ }^{4}$ in barbitone buffer $p H$ 8.6, using a constant current of $0.5 \mathrm{~m}$. amp/cm for $1.25 \mathrm{~h}$. A staining solution the composition of which is based on Oliver's method for CPK determination ${ }^{5,6}$ is prepared as follows:

Adenosine-5-diphosphate sodium salt (C. F. Boehringer and Son), $2 \mathrm{mg}$; hexokinase (C. F. Boehringer and Son), $10 \mu l$. (2.8 I.U.); glucose-6-phosphate dehydrogenase (C. F. Boehringer and Son), $10 \mu \mathrm{l} .(1 \cdot 4$ I.U.); glucose, $2 \mathrm{mg}$; magnesium sulphate $\left(\mathrm{MgSO}_{4} .7 \mathrm{H}_{2} \mathrm{O}\right), 7 \mathrm{mg}$; nicotinamido adenine dinucleotide phosphato (NADP, or TPN, C. F. Boehringer and Son), $3 \mathrm{mg}$; MTT (3-(4,5-dimethylthiazolyl-2)-2,5-diphenyl tetrazolium bromide; (George $\mathrm{T}$. Gurr, Ltd.), 1.6 mg 0.05 M tris buffer $p \mathrm{H} .7 \cdot 5,3 \mathrm{ml}$.

This solution is divided into equal parts, and $5 \mathrm{mg}$ creatine phosphate (C. F. Boehringer and Son) added to half to constitute the test solution, the remaining half serving as a control solution. Immediately prior to use, $80 \mu l$. of phenazine methosulphate ( $N$-methyl-phenazonium methosulphate; British Drug Houses, Ltd.), froshly dissolved in distilled water at a concentration of $1 \mathrm{mg} / \mathrm{ml}$., are added to both test and control.

Following electrophoretic separation, the cellulose acetate is divided longitudinally, and one half-strip is stained for CPK activity using the test solution. The remaining half-strip is stained with tho control solution. For staining, a layering technique is used?, the half-strip being layered on to an additional cellulose acetate strip which has been allowed to soak up staining solution. Both strips are incubated in a moist chamber for $1 \mathrm{~h}$ at $37^{\circ} \mathrm{C}$.

Fig. 1 illustrates the results obtained by the examination of adult human muscle homogenates. Muscle was homogenized at a concentration of $50-100 \mathrm{mg}$ wet weight of tissue per ml. in distilled water, using a Potter-Elvehjem homogenizer. The homogenate was lightly centrifuged $(2,000$ r.p.m.) for $10 \mathrm{~min}$, and the supernatant diluted with distilled water to yield a CPK activity of approximately 2,000-4,000 I.U. per litre by Hughes's method ${ }^{8}$. Two sera of activities 5,500 and 3,900 I.U. per litre, from patients with muscular dystrophy of Duchenne type (kindly supplied by Dr. B. P. Hughes of the National Hospital, London), were also examined.

Cardiac muscle showed a major staining band with a mobility intermediate between that of serum $\beta$ - and $\gamma$-globulins. A minor component with a mobility of that of an $\alpha-2$ globulin was also demonstrable. No staining of

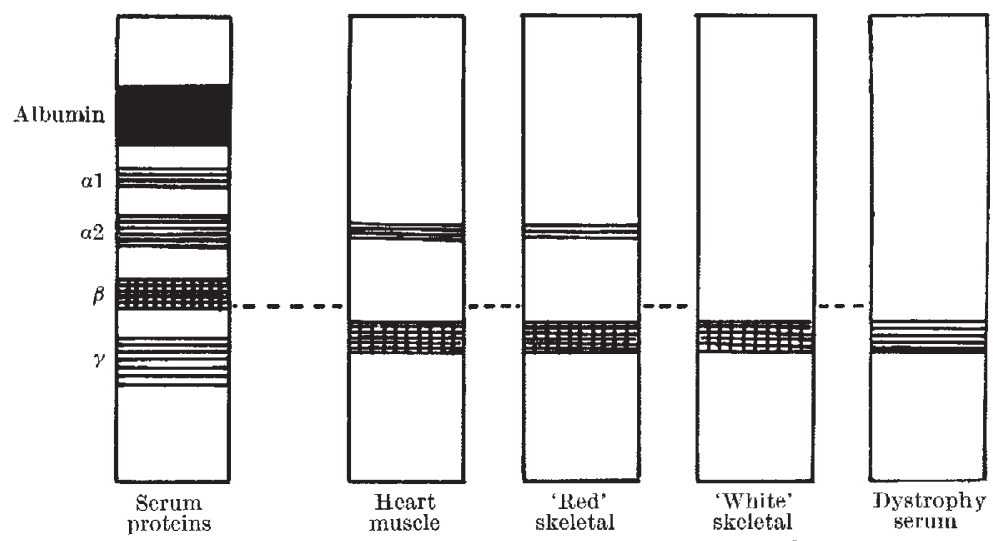

Fig, 1. Crentine phosphokinase isoenzymes of muscle the control strips was observed. A similar isoenzyme pattorn was obtained with three specimens of skeletal muscle shown by histochemical and biochemical means to be composed chiefly of 'red' muscle fibres'. Three spccimens of skeletal muscle similarly shown to be composed chiefly of 'white' muscle fibres showed only the major isoenzyme band. The sera from the two patients with muscular dystrophy showed only the major component.

\section{S. B. Rosalki}

St. Mary's Hospital,

London, W.2.

${ }^{1}$ Burger, A., Richterich, R., and Aebi, H., Biochem. Z., 339, 305 (1964).

2 Deul, D. H., and van Breemen, J. F. L., Clin. Chim. Acta, 10, 276 (1964).

${ }^{3}$ Sjövall, K., and Voigt, A., Nature, 201, 701 (1964).

“ Kohn, J., Clin. Chim. Acta, 2, 297 (1957).

' Oliver, I. T., Biochem. J., 81, 116 (1955).

6 Nielsen, P., and Ludvigsen, B., J. Lab. Clin. Med.., 62, 159 (1963).

7 Barnett, H., J. Clin. Path., 17, 567 (1963).

${ }^{8}$ Hughes, B. P., Clin. Chim. Acta, 7, 597 (1962).

- Beckett, E. B., Rev. Canud. Biol., 21, 391 (1962).

\section{Effect of Urea on the Cold Precipitation of Protein in the Lens of the Dogfish}

When lenses of young rats are cooled bolow $10^{\circ} \mathrm{C}$ they become reversibly opaque due to the precipitation of a cold-precipitable protein. This fraction is prepared by homogenizing rat lenses in several volumes of water and cooling the $105,000 \mathrm{~g}$ supernatant to $0^{\circ} \mathrm{C}$. Repeated solubilization at $20^{\circ} \mathrm{C}$ and precipitation at $0^{\circ} \mathrm{C}$ serves as a moans of purification ${ }^{1}$. The cold-precipitation phenomenon is thought to be caused by changes in protein conformation due to a disturbance of the balance between hydrogen and hydrophobic bonding of protcin chains at lower temperatures.

Purified rat lens cold-precipitable protein was found to be homogeneous in the analytical ultracentrifuge (with a $4 s$ sedimentation rate at $20^{\circ} \mathrm{C}$ ), but was shown to be heterogeneous by means of acrylamide gel electrophoresis, agarplate immunodiffusion, and 'Sephadex $G-100^{\text {' gel filtration }}$ investigations ${ }^{2}$. Cold-precipitable protein was found to contain species similar to the $\alpha-, \beta$ - and $\gamma$-crystallin protein fractions of the lens. Cold precipitation was dependent on the concentration of protein, the ionic strength and the $p \mathrm{H}$ of the solution containing cold-precipitable protein.

Further work indicated that a urea level of $0.25-0.3 \mathrm{M}$ tended to inhibit the phenomenon of cold precipitation ${ }^{3}$. This observation led to the present investigation of the effect of the relatively high tissue concentration of urea $(0 \cdot 25 \mathrm{M})$ on dogfish lens cold-precipitable protein.

Initial invostigations demonstrated that intact dogfish (Mustelis canis) lenses did not become opaque on cooling. Preparation of the dogfish lens cold precipitable protein fraction therefore required extensive dialysis of the $105,000 \mathrm{~g}$ supernatant against water in order to romove urea and thus to allow cold precipitation to occur. When $0.25 \mathrm{M}$ urea was added back to a preparation of cold-precipit. able protein, cold procipitation was preven ted.

Dogfish lens cold-precipitable protein exhibits characteristics similar to that of the rat lens. It docreases in concentration as the animal anges from a level of 17 per cent of the total soluble protein in the young dogfish and 35 per cent in the foetal rat lens to 57 per cent in, the lenses of older animals. In both species the cold-precipitable protein fraction contains 1.5 per cent (by weight) RNA. Ultracentrifugal analysis of the dogfish or rat lens cold-precipitable protein at $20^{\circ} \mathrm{C}(p H$ $8 \cdot 0$ ) reveals a single peak with a sedimentation rate of $4 S$ as compared to the 